\title{
PENERAPAN PROTOKOL KESEHATAN 5 M PADA MASYARAKAT LAPAS WANITA KELAS I A TANJUNG GUSTA MEDAN
}

\author{
Sontina Saragih ${ }^{1}$, Catherine ${ }^{2}$, Nurlela Petra Saragih ${ }^{3}$ \\ ${ }^{1,2}$ Akademi Keperawatan Columbia Asia, Medan, Indonesia \\ ${ }^{3}$ Universitas Prima Indonesia, Medan, Indonesia \\ ${ }^{1}$ sontinasaragih@yahoo.com, ${ }^{2}$ catherine.tjong@ hotmail.com, ${ }^{3}$ nurlelapetrasaragih@unprimdn.ac.id
}

\begin{abstract}
ABSTRAK
Pencegahan penyebaran novel coronavirus sangat penting dilakukan karena rute penyebaran melalui permukaan sangat cepat. Masyarakat yang terinfeksi SARS-CoV-2 dapat sebagai pembawa dan menjadi pre-asimtomatik dalam penyebaran COVID-19. Sejak WHO mengumumkan bahwa COVID-19 merupakan pandemic secara global di seluruh dunia. Penyebaran COVID-19 yang terjadi di masyarakat telah menyebar dengan luas dan cepat. Sehingga perlu dilakukan cara untuk mencegah penyebaran COVID-19. Menurut laporan WHO 78-85\% terjadi infeksi dengan cluster family sejak dimulainya gelombang pertama COVID-19 di China. Type mayor cluster infeksi family menyebar melalui komunitas, infeksi nosocomial, bersalaman, transportasi, kegiatan keagamaan, kantor, penjara, pusat perbelanjaan, dan perawatan di rumah. Lima penjara dengan epidemic COVID-19 dilaporkan 511 terkonfirmasi dengan COVID-19 yang terjadi di China. WHO mengeluarkan panduan untuk merespon penyebaran COVID-19 di penjara dan merekomendasikan kepedulian dan petugas kesehatan bergabung untuk mengurangi risiko, mencegah dan mengontrol, pengobatan, dan membagi informasi. Untuk mencegah penyebaran COVID-19 WHO mengeluarkan pedoman penyebaran dengan melakukan memakai masker, mencuci tangan, menjaga jarak, mengindari kerumunan, membatasi aktivitas. Dari pemaparan diatas perlu dilakukan penyuluhan pencegahan COVID-19 di lapas wanita kelas IA.
\end{abstract}

Kata Kunci: Protokol kesehatan, 5 M, Masyarakat Lapas

\begin{abstract}
Prevention of the novel spread of coronavirus is very important because the route of spread through the surface is very fast. People infected with SARS-CoV-2 can be carriers and become pre-asymptomatic in the spread of COVID-19. Since WHO announced that COVID-19 is a global pandemic around the world. The spread of COVID-19 in the community has spread widely and rapidly. So there needs to be a way to prevent the spread of COVID-19. According to the WHO report $78-85 \%$ of infections with family clusters have occurred since the start of the first wave of COVID-19 in China. Major cluster types of family infections spread through communities, nosocomial infections, shaking hands, transportation, religious activities, offices, prisons, shopping malls, and home care. Five prisons with the COVID-19 epidemic reported 511 confirmed with COVID-19 occurring in China. Who issued guidelines to respond to the spread of COVID-19 in prisons and recommended that care and health workers join forces to reduce risk, prevent and control, treatment, and information sharing. To prevent the spread of COVID-19 WHO issued spread guidelines by wearing masks, washing hands, keeping distance, avoiding crowds, limiting activity. From the above exposure, covid-19 prevention counseling is needed in class IA women's prisons.
\end{abstract}

Keyword :Protocol Health, 5M, Prison 


\section{Pendahuluan}

Novel coronavirus SARS-CoV-2, yang dikenal sebagai COVID-19 oleh Organisasi Kesehatan Dunia (WHO) sejak 11 February 2020, merupaka pathogen $\beta$ coronavirus dimana menginfeksi manusia. COVID-19 ini didiagnosis dimulai dengan infeksi pada tenggorokan.

Penderita COVID-19 di seluruh dunia semakin meningkat, berdasarkan data dari Thelancet (2021) ada 750.000 pasien dengan COVID-19 dengan risiko tinggi disfungsi acut brain (koma dan delirium). Kasus COVID-19 darurat terdapat di masyarakat lapas sebagai penyebaran infeksi yang cepat, dan menjadi sorotan dimana ' kesehatan masyarakat lapas adalah kesehatan public." Sebagian sel masyarakat lapas padat ( sel area lantai per orang) adalah telah disiapkan secara metric sejak dilakukan pengukurannya (penggunaan sel di lapas dibagi berdasarkan kapasitas populasi masyarakat di lapas. Faktor factor yang menjadi penyebaran virus COVID-19 di sel yang padat adalah usia, tingkat pendidikan, kondisi medis (penyakit kronis), penggunaan obat terlarang, ventilasi lingkungan, lokasi sel, akses servis masyarakat lapas, dan keluar masuknya kunjungan ke lapas.

Perlu dilakukan perbaikan kebersihan dan skrining kepada masyarakat lapas, pemeriksaan, dan mengisolasi yang sudah terpapar, membuat prioritas strategis untuk kesehatan umum masyarakat lapas dan mulai meningkatkan pencegahan terpaparnya COVID-19 dengan melakukan penerapan protokol kesehatan $5 \mathrm{M}$.

Berdasarkan data dari Lapas Narkotika Sleman terdapat 275 orang terpapar dengan COVID-19, dan dilakukan isolasi di lapas tersebut. Oleh karena itu perlu dilakukan edukasi penerapan protokol kesehatan 5M di masyarakat lapas wanita kelas IA.

Tujuan dilakukannya pengabdian masyarakat ini adalah agar masyarakat lapas wanita kelas IA di Tanjung Gusta Medan dapat menerapkan protokol kesehatan $5 \mathrm{M}$ (cuci tangan, memakai masker, jaga jarak, menghindari kerumunan, membatasi kegiatan/mobilitas fisik).

\section{Metode}

Berdasarkan data dari Lapas Wanita Kelas II A yang telah didapatkan bahwa banyaknya jumlah masyarakat yang terdapat di dalam tidak sesuai dengan kapasitas yang ada dan tidak melakukan protokol kesehatan sebagaimana yang telah dianjurkan oleh pemerintah. Kegiatan dilakukan dalam bentuk proses pembuatan media edukasi berbasis website. Evaluasi kegiatan dilakukan dengan bersama sama mempraktekkan penerapan protokol kesehatan 5M yaitu mencuci tangan, memakai masker, menjaga jarak, membatasi aktivitas fisik, menghindari kerumunan dan melakukan tanya jawab dan diskusi sesuai materi.

\section{Hasil dan Pembahasan}

\section{Hasil Pelaksanaan}

Pengabdian dilaksanakan selama 6 jam pada tanggal 24 Juni 2021 di Lapas Kelas I A Tanjung Gusta, dengan dihadiri oleh pimpinan Lapas Wanita, masyarakat lapas wanita. Pelaksanaan dilakukan dengan tiga tahapan yaitu persiapan, pelaksanaan dan evaluasi. Pimpinan Lapas Wanita memberikan kata sambutan dan setelah itu dilanjutkan dengan 
presentasi seminar penerapan protokol $5 \mathrm{M}$. Setelah selesai presentasi seminar fasilitator melakukan penerapan protokol kesehatan $5 \mathrm{M}$ dengan cara cuci tangan, memakai masker menjaga jarak, menjahui kerumunan, dan membatasi mobilisasi. Masyarakat Lapas Wanita Kelas IA yang hadir sebanyak 40 orang. Pelaksanaan pemaparan materi dan penerapan mencuci tangan, memakai masker, menjaga jarak, menjahui kerumunan, dan membatasi mobilisasi berlangsung selama 2,5 jam. Materi yang disampaikan penerapan protokol kesehatan $5 \mathrm{M}$ yaitu mencuci tangan, memakai masker, menjaga jarak, menjahui kerumunan, dan membatasi mobilisasi. Pada acara selanjutnya diberi kesempatan untuk diskusi atau bertanya.

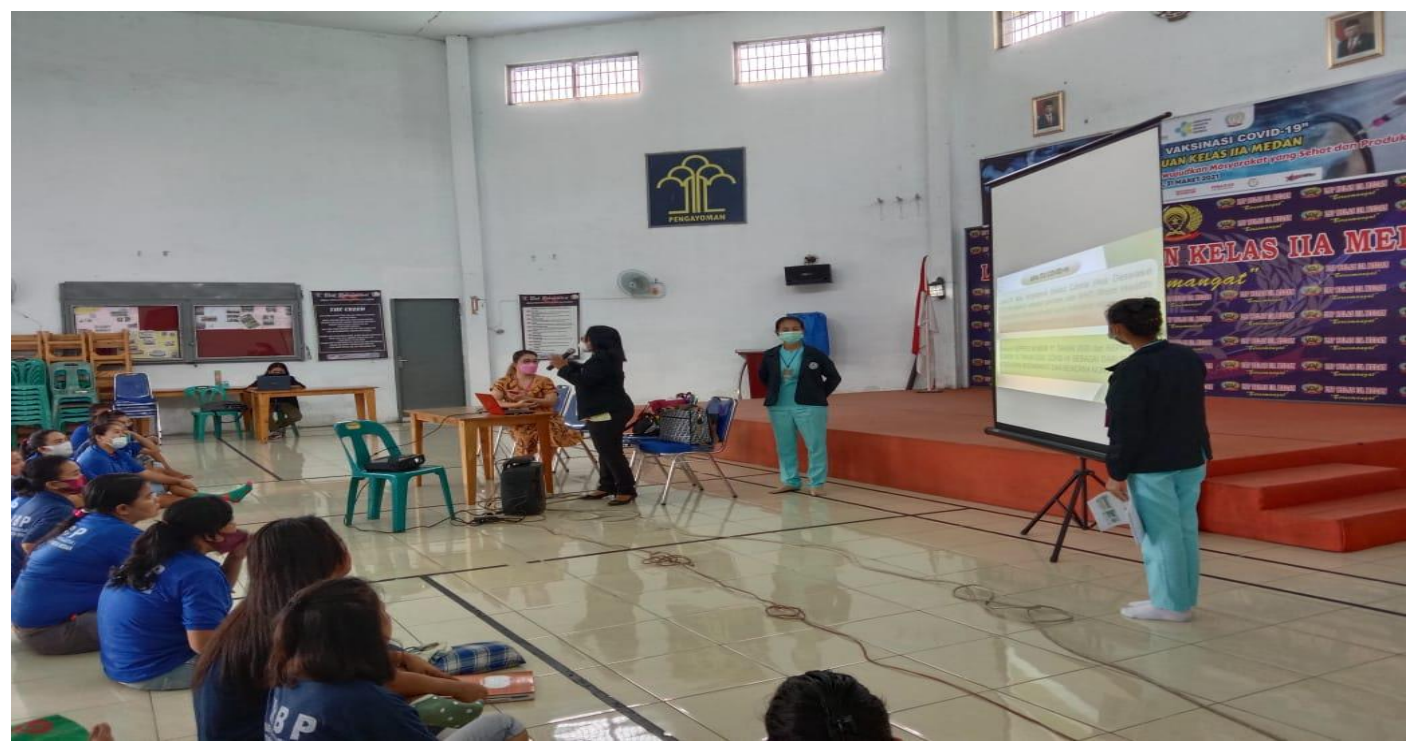

Gambar 1. Pemaparan Materi

Setelah dilakukan penerapan protokol kesehatan 5M : mencuci tangan, memakai masker, menjaga jarak, menghindari kerumunan dan membatasi mobilisasi didapatkan hasil masyarakat lapas wanita kelas IA mencuci tangan 80\%, memakai masker $100 \%$, menjaga jarak 100\%, menjahui kerumunan 80\%, dan membatasi mobilisasi $85 \%$.

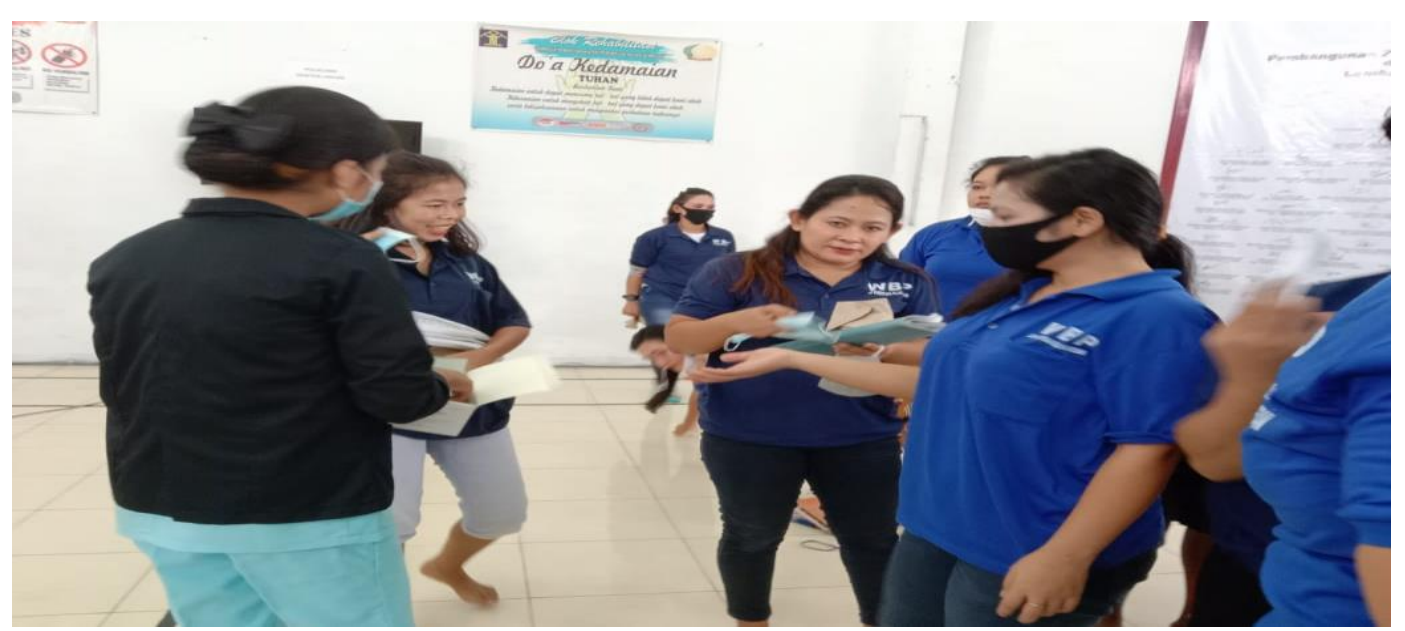

Gambar 2. Pembagian Leaflet Protokol Kesehatan 5M 


\section{Pembahasan}

Penyakit Coronavirus 2019 (COVID-19) pertama sekali dideteksi di China pada Desember 2019, dan dideklarasikan oleh Organisasi Kesehatan Dunia menjadi sebuah pandemi. Penanganan COVID-19 ini diperlukan managemen yang secara umum berdasarkan therapy yang mendukung dan perlu dilakukan evaluasi untuk penanganan tersebut. COVID-19 ini sangat cepat penyebarannya, dimana penyebarannya ini melalui droplet sekresi pernafasan dan langsung masuk ke dalam tubuh. Terjadinya penyebaran droplet tersebut ketika seseorang bersin dan batuk, virus keluar melalui sekresi pernafasan, oleh karena itu tidak boleh menyentuh pemukaan objek, menyentuh mulut, hidung dan mata. Untuk menghindari percikan droplet dan virus dilakukan control yang ketat seperti dilakukan isolasi bagi yang terpapar, sering mencuci tangan, social distancing, memakai masker, pembatasan aktivitas dan menghindari kerumunan untuk mencegah terpaparnya dari COVID-19.

Masyarakat lapas yang penghuninya padat dan sel yang terbatas untuk tertularnya COVID-19 mempunyai risiko yang tinggi. Untuk itu diperlukan managemen yang baik untuk menghindari COVID-19, dengan melakukan promosi kesehatan, menyamakan persepsi dengan masyarakat lapas wanita kelas IA. Upaya yang dilakukan kepada masyarakat lapas wanita kelas IA adalah dengan melakukan edukasi penerapan protokol kesehatan $5 \mathrm{M}$ yaitu pertama : dengan sering melakukan cuci tangan di air mengalir dengan menggunakan sabun atau desinfektan selama lebih kurang satu menit, dapat juga dilakukan dengan mencuci tangan memakai hand sanitizer yang mengandung antiseptic atau alcohol selama dua puluh sampai tiga puluh detik dan menghindari menyentuh daerah wajah, mukosa hidung, mukosa mulut dan menyentuh mata. Penerapan protokol kesehatan yang kedua adalah dengan memakai masker yang mempunyai lapis 3 dan di double yaitu masker menutup area hidung dan mulut. Untuk memastikan apakah masker yang dipergunakan sudah tepat adalah dengan menghembuskan udara dari mulut apabila terdapat udara yang keluar dari masker dan kacamata seperti ada embun berarti pemakaian masker belum tepat. Pemakaian masker ini sangat penting dilaksanakan di masyarakat lapas wanita kelas IA mengingat jumlah huni masyarakatnya yang ramai. Penerapan protokol kesehatan yang ketiga adalah dengan menjaga jarak minimal 1-1,5 meter. Untuk lebih amannya adalah 6 meter jika seseorang yang terpapar batuk atau bersin tanpa menggunakan masker maka orang yang disekitarnya tidak terpapar. Penerapan protokol kesehatan yang ke empat adalah dengan menghindari kerumunan, maka alangkah baiknya jika tetap berada di rumah untuk menghindari kerumunan atau keramaian tersebut. Penerapan protokol kesehatan yang kelima yaitu dengan melakukan pembatasan aktivitas/ mobilitas. Masyarakat lapas wanita kelas IA sering melakukan kunjungan dengan sel lainnya yang bisa membawa virus ke tempat lain.

Dampak dari pemberian penyuluhan penerapan protokol kesehatan di atas masyarakat lapas wanita kelas IA Tanjung Gusta Medan adalah masyarakat dapat menerapkannya di lingkungan masyarakat agar terhindar dari COVID-19.

\section{Kesimpulan}

Edukasi penerapan protokol kesehatan yang dilakukan pada masyarakat lapas wanita kelas IA berlangsung dengan baik dan berjalan dengan lancer dan masyarakat lapas wanita dapat merubah perilaku protokol kesehatan $5 \mathrm{M}$ dengan baik. 


\section{Referensi}

Brenda T Pun, Rafael Badenes et al (2021). Prevalence and risk factors for delirium in critically ill patient with COVID-19 (COVID-D): a multicenter cohort study. Lancet REspirMed 2021: 9: 239-50

Elahe Seyed Hosseini, Narjes Riahi Kashani. (2020). The novel coronavirus Disease2019 (COVID-19): Mechanism of action, detection and recent therapeutic strategies, Virolgy 551 (2020) 1-9.

Kemenkes RI. (2020). Protokol Tata Laksana COVID-19, Edisi 2, 2021

Khaled Habas, Chioma Nganwucu. (2020). Resolution of coronavirus disease 2019 (COVID-19), Expert Riview of Anti -Infective Therapy, 2020,Vol. 18. No. 12, 1201-1211

Paul L Simpson, Tony G Butler. (2020). Covid-19, prison crowding, and release policies

Tao Liu, DExin Gong. (2020). Cluster infection play important roles in the rapid evolution of COVID-19 transmission: A systematic review.

Xinhuanet. Five prison epidemics occurred in three provinces in China. (2020)

Zhang W, Du R-H, Li B, et al. Molecular and serological investigation of 2019-nCov infected patients: implication of multiple shedding routes, Emerg Microbes Infect. 2020;9(1):386-389 